\title{
English Words and Phrases in Croatian: A Small- Scale Study of Language Awareness and Attitudes
}

\author{
ABSTRACT
}

The focus of this paper is on language attitudes towards English words and phrases in the Croatian language. In order to prevent loanwords, linguistic purism has arisen as a theory about what languages should be like. The tradition of linguistic purism in Croatia has been shaped by various socio-historical factors. English may be viewed as a language of opportunity, or as a threat to the survival of other, usually minority and endangered, languages. In order to provide an insight into the use of English words and phrases in the Croatian context, a questionnaire about language attitudes and awareness was conducted on 534 participants. The aim of the questionnaire was to determine participants' language attitudes and familiarity with English words and phrases. The results show that although people in Croatia generally like English, many of them are not familiar with English words, especially older participants and those with little or no knowledge of the English language. Moreover, the results indicate that the younger generation is more inclined towards English than the older generation; however, they are not as familiar with Croatian equivalents as they claim.

Keywords: language contact; borrowing; attitudes; linguistic purism

\section{Angleške besede in besedne zveze $\mathbf{v}$ hrvaščini: Študija jezikovne osveščenosti in odnosa do jezika}

\author{
POVZETEK
}

Članek se osredinja na odnos do angleških besed in besednih zvez v hrvaškem jeziku. Iz potrebe, da bi preprečili rabo tujk v jeziku, je postal jezikovni purizem teorija o tem, kakšni naj bodo jeziki. Na Hrvaškem so tradicijo jezikovnega purizma oblikovali različni družbeno zgodovinski dejavniki. Angleščina je lahko jezik priložnosti, lahko pa je tudi grožnja za preživetje manjših in bolj ogroženih jezikov. Z namenom dobiti vpogled v odnos in ozaveščenost glede rabe angleških besed in besednih zvez v hrvaščini, smo opravili anketo med 534 udeleženci. Cilj vprašalnika je bil ugotoviti poznavanje ter odnos udeležencev do angleških besed in besednih zvez. Rezultati so pokazali, da imajo ljudje na Hrvaškem v glavnem radi angleščino, vendar veliko starejših udeležencev in tistih s šibkim znanjem angleščine ne pozna angleških besed in besednih zvez. Ne drugi strani pa rezultati kažejo, da so mladi bolj naklonjeni angleščini kot starejši, vendar je njihovo poznavanje hrvaških ustreznic angleških besed in besednih zvez slabše, kot trdijo.

Ključne besede: jezikovni stik; izposojenke; odnos; jezikovni purizem 


\section{English Words and Phrases in Croatian: A Small- Scale Study of Language Awareness and Attitudes}

\section{Introduction}

Attitudes towards a language tend to change as the language becomes global, as it gradually begins to spread around the world. Attitudes towards a global lingua franca are particularly interesting from the point of view of non-native speakers. Such individuals may be highly motivated to learn the language, or they may see it as a threat to their mother tongue (Crystal 2003,3). It seems that both of these conflicting attitudes are present to varying degrees in the Croatian context, which is something that the results of this research might shed some light on. English has indisputably gained a symbolic status in the context of modern development. From the purely linguistic point of view, this is confirmed by analyses of instances of borrowing which are predominantly linked to different semantic fields, such as technological advancement, international relations and the media (Cooper 1989, 152; Berns et al. 2007, 19; Vikør 2004, 332). The spread of any linguistic variety is facilitated by the possibility of describing it as socially neutral and unmarked. This is true for English as it is described as "culturally neutral" and not bound to the British or American culture (Berns 2007, 5). The incredibly fast spread of international communication is another factor contributing to the spread of English. Apart from the exposure to different types of mass media, the Internet has become the crucial element for sociolinguistic analyses of language presence (Cook 2003, 26; Holliday et al. 2004, 96; Thurlow 2001, 287).

The prestige of English is fairly obvious and understandable as it has become the dominant language in the world today. It plays a large role in Croatia as well, which is evident in, among other areas, its distribution in the names of companies (Croatian Airlines, Croatia Records), newspapers and magazines (Bug, Story), but also the types of apples (golden delicious, granny smith) (Kovačić 2007, 65). These examples could also be analysed according to the distinction between necessary and luxury loans, ${ }^{1}$ i.e. catachrestic and non-catachrestic innovations (Onysko and Winter-Froemel 2011, 1550-67). The names of companies (Croatian Airlines, Croatia Records) as well as newspapers and magazines (Bug, Story), could, therefore, be defined as luxury loans, because they are not adapted to the Croatian language and are not necessary, but are used for the purpose of international communication and for achieving competitiveness of a product on the international market. On the other hand, the types of apples (golden delicious, granny smith) could be defined as necessary loans because they are currently used in their adapted form, for example, in supermarkets as greni smit, zlatni delišses (see Winter-Froemel and Onysko 2012, 45-49, on the relationship between necessary loans and adaptation).

Despite, or even because of, its overwhelming presence, many linguists have campaigned against the usage of English in various sociolinguistic contexts. Such activities are evident among Croatian linguists as well. Throughout its history, Croatia was oppressed politically and linguistically by many countries. The lack of a consistent language policy in Croatia could be due to sociohistorical factors including the fact that for a long time the mere existence of the language has been questioned by invading foreign forces. However, nowadays such an explanation simply does not hold. As Opačić $(2009$, 50) points out, Croatia is finally an autonomous country,

In this paper, we use the term loanword or loan instead of borrowing, although both terms are misleading because they imply returning of the borrowed element after some time (Aitchison 2001, 141). 
oppressed by no one, and there is still no language policy which would regulate the language and the amount of unnecessary loanwords.

The aim of this paper is to provide some insight into the importance of linguistic purism, in particular, attitudes in the Croatian sociolinguistic context, and to explore these issues in practice. The hypotheses of the research are the following: the younger generation is more familiar with popular English words and phrases and, therefore, uses them more often. They do not consider the increasing number of English words a problem, nor are they aware of the danger of such exposure to foreign linguistic influences. On the other hand, the older generation, not being as familiar with popular culture and the Internet, will avoid using English and will prefer Croatian equivalents. As far as education is concerned, people with a lower educational level will have the same attitudes as the older generation, while the more educated participants will be more open to the influence of English. Higher proficiency in English among informants is assumed to result in higher tolerance towards loanwords, while among those who have learnt English less than 4 years or have never learnt English there will presumably be a preference for Croatian equivalents and a lower tolerance for mixing English elements in everyday language.

Furthermore, this research could greatly benefit from the inclusion of a pragmatic perspective, i.e. analysis of borrowing of discourse markers, interjections, expletives, and vocatives, such as 'yeah, right,' 'sorry' or 'hello' (Andersen 2014, 17-33). Various scholars have already contributed significantly to this area, namely Prince (1988) as one of the first scholars to explore pragmatic borrowing, Andersen (2001) with his research on pragmatic markers and sociolinguistic variation, and Clyne $(1972,98-110 ; 1977,130)$ with an emphasis on perspectives on language contact and intercultural communication. Although a pragmatic perspective would most likely produce interesting results in analysing contact between English and Croatian (especially the investigation of discourse markers such as sorry or yeah, right), it is not included in this paper because such a perspective would require a new case study. Moreover, the analysis of this type of transfer is most productive in contexts of emphasized cultural, i.e. sociolinguistic, differences, which is the case, e.g., between Chinese and English (Liu 2010).

\section{Borrowing as a Result of Language Contact}

Every language changes in various ways and at different rates. Numerous linguistic changes are implemented without any conscious effort, mainly due to various sociohistorical circumstances and language contact. During this process, some languages are more open to foreign influences than others. In fact, contact with other languages has greatly affected English. Throughout its history, English has tended to borrow words rather than create new ones; for example, it is estimated that $75 \%$ of its vocabulary is derived from French and Latin loanwords (Thomason $2001,10)$. Today, as the world's international language, it has become the source of borrowing.

Borrowing is also referred to by the term 'importation' (Clyne 2003, 70; Romaine 2004, 49). From the structural point of view, borrowed elements might retain their original structure. In many cases they go through the process of nativization. Thus, phonological, grammatical and even orthographic features become adapted to the system of the receiving language (Jackson $1988,22)$. Although it may seem that the reasons for borrowing are simple, they cannot be reduced to their essential communicative function, that is, lack of particular primary or conceptual meaning in the receiving language. More often, borrowed words function as stylistic or as social distance markers (Leith 1997, 52). Apart from analysing general motives for adopting 
loanwords, Kowner and Rosenhouse (2008, 12-16) list the determinants for borrowing English vocabulary: modernization and economic development, prestige, ethnic and linguistic diversity, nationalism, cultural threat, national character, and existence of regulatory linguistic establishments. Although our research will not focus on the extent of the role of each of these determinants in the Croatian context, it is clear that each of them plays a role in the process of borrowing and in the usage of borrowed words.

Once words from a source language enter the target language, it seems that both individual and collective attitudes and judgments define their actual usage. In describing languages, expressions such as "more beautiful" and "more logical" (Milroy and Milroy 1999, 11) are often heard. These assumptions and presuppositions about the prestige of one language over another cannot be proven; however, neither can the fact that they are equal. After all, all languages and variants should be treated equally. Nevertheless, it appears that value judgements about different linguistic varieties are very common. Such judgements can be the result of prejudice or mirroring a value judgement about an individual to his linguistic usage (Suarez Büdenbender 2013, 110; Simpson $2001,295)$. Before a more thorough insight into language attitudes is presented, an overview of the status of linguistic purism in the Croatian sociolinguistic context will be provided.

\section{Linguistic Purism - The Croatian Perspective}

In the 1990s, within the European context, different minority languages were subjected to notable changes (O'Reilly 2001, 1). This is especially true with regard to languages on territories which had experienced the dissolution of larger sociopolitical units. Languages become strong symbols of national identity in attempts to achieve political independence. Before the dissolution of former Yugoslavia, efforts were made to linguistically unite the territory by means of the Serbian language. This failed because the language was not considered neutral (Tišljar 2002, 37). However, puristic tendencies have been present in Croatia long before Serbian became their focus. Most recently, such tendencies have been oriented against Anglicisms as well (Drljača Margić 2014, 73). A feeling of threat is usually the source of negative attitudes towards a language (Kotze 2001,327), which is applicable to the Croatian puristic tradition as well. In attempts to distance Croatian and Serbian languages, some Croatian linguists not only searched for differences between the two languages, but also, according to some linguists, even made them up (Anić 1998, 42).

Although there are linguists who are raising concerns about the influx of Anglicisms in the Croatian language, the fact is that in actual linguistic usage such loanwords are on the increase. What seems to be happening is a change in attitudes concerning Croatian, which is related to changes in the political situation. When language is threatened, we value our language emotionally and protect it from foreign influences. On the other hand, when there is no threat, we evaluate our language rationally (Tišljar 2002, 52-53). Today, some linguists see English as a threat to Croatian and some do not, which has resulted in two main tendencies: puristic and liberal views.

\subsection{Purists}

In the first half of the 1990s, purists such as Stjepan Babić, Miro Kačić and Mate Šimundić made attempts to purify Croatian from Serbianisms (Oczkowa 2010, 328). Even back in 1953, Croatian linguists talked about purism. For example, Ljudevit Jonke (1953/4, 4) appealed against the use of unnecessary foreign words and underlined the snobbery of certain writers who used foreign words just to sound educated. Back in 1986, Filipović wrote about the openness 
of Croatian to foreign influences and borrowing of foreign words (1986, 15). He also analysed Anglicisms according to their phonological, morphological and semantic adaptation (1990, 26). More recently, Stjepan Babić $(2004,215 ; 2001,248)$ has warned against the threat of Anglicisms. He focuses on words which are borrowed not as a result of need, but due to commodity and carelessness (Babić 1995, 11).

In today's world, it is clear that our speech is influenced by television and the Internet. This becomes an issue when most of our private linguistic practice is directly associated with public language (Kryzan-Stanojević 2013, 202), where not only lexical items, but also morphemes and phrases are taken over (Belaj 2009, 262). Drljača Margić (2014, 74) outlines the attitudes of linguists who propose that "the use of Anglicisms (in the media) clearly reflects Croatian speakers' snobbery, sycophancy, indifference, conformism and spiritual laziness." One of the harshest contemporary critics is Nives Opačić, who in her numerous articles and books warns of the impoverishment of Croatian vocabulary and replacement of good Croatian words with the English ones; moreover, she states that the influx of Anglicisms has become "completely uncontrollable" (Opačić 2007, 217). Furthermore, she argues against the popular fallacy regarding the use of English to express something that is linguistically more concise and economical. As an illustration, she offers the following examples: 'on the record' and 'off the record,' which can be expressed more compactly in Croatian: 'službeno' and 'neslužbeno' (Opačić 2006, 128).

\subsection{Liberals}

On the other hand, the liberal view is championed by authors such as Ivo Pranjković, Vladimir Anić, Marko Samardžija, Josip Silić and others, who advocate a more relaxed attitude towards language development and argue against artificially cleansing the language of loanwords (Oczkowa 2010, 329). Moreover, they describe such purism as unnecessary and even detrimental. Vladimir Anić $(1998,42)$ emphasizes the importance of self-respect and conscious choice in the creation of the culture of Croatian, stating that it cannot be exclusively determined by the views of "language offices." Ivo Žanić $(2013,216)$ argues that the Croatian standard language is not jeopardized because not all of its domains or functional styles are satiated with Anglicisms.

In short, liberals do not view Anglicisms as a danger or threat to the Croatian language and claim that purists are exaggerating the problem. Snježana Kordić $(2010,23)$ claims that purism is not, and has never been, the dominant view in Croatia towards borrowing, but that it is a construct of a group of linguists. Many anti-purists, Kordić included, refer to concepts of "falling standards" and "moral panic" (Cameron 1995, 40; 83), which are frequently used by purists as arguments to further their puristic campaigns. By analysing these concepts it is possible to discern a type of linguistic ideology that rests on pleas for preserving what is believed to be appropriate not only in linguistic, but also in social, cultural and moral terms.

Similar linguistic ideologies that rest on puristic tendencies are visible in the investigation of numerous linguistic policies, both in neighbouring and more distant sociolinguistic contexts. Such tendencies vary in degree from one context to another and, besides linguistic factors, frequently depend on various non-linguistic ones, such as historical, cultural and political relations.

\section{Language Attitudes}

Linguistic varieties are important factors in evaluation and perception of those who use them (Meyerhoff 2006, 54; Kramsch 2004, 235; Paddila 1999, 113). There have been numerous 
attempts to define the concept of attitude. It is difficult to pinpoint an exact definition because the concept overlaps with other concepts in social psychology such as 'belief,' 'opinion,' 'value,' 'habit', 'trait', 'motive' and 'ideology' (McKenzie 2010, 19-20; Baker 1992, 15; Garrett 2010, 31-33). In analysing attitudes, it is important to take into consideration the concept of intensity, as stronger attitudes will have a greater impact on evaluative judgements and subsequent behaviour (McKenzie 2010, 25). Stronger attitudes are, consequently, crucial in attempts to identify and measure them. It is important to note that attitudes cannot be measured directly but are inferred from behaviour or measured through self-report questionnaires and interviews (Lasagabaster and Gasteiz 2004, 399-401; Bainbridge 2001, 82; Baker 1992, 11). Attitudes may serve different functions (for an overview see e.g., McKenzie 2010, 24-25; Brown 2006, 51; Lasagabaster and Gasteiz 2004, 401-2); however, as far as language attitudes are concerned, social ones seem to be crucial.

Language attitudes are significant both on the macrosociological and the microsociological level (Giles and Billings 2004, 187-88). This is also true for the analysis of the inflow of Anglicisms in the Croatian language, where it might be argued that those on the macrosociological level precede those on the microsociological level. On the other hand, in distinguishing between instrumental and integrative language attitudes (Baker 1992, 32), it is argued that integrative language attitudes are usually created in relation to one's mother tongue (Liebkind 1999, 144). Thus, it would appear that instrumental language attitudes are more prominent in contexts of analysing Anglicisms in Croatian as English primarily plays an instrumental rather than integrative role.

In addition to research on native speakers' attitudes towards English, there are also numerous studies that have concentrated on the attitudes of non-native speakers. McKenzie $(2010,59)$ notes that although there are some concerns about the endangerment of native languages, most results show a predominantly positive attitude towards the English language. However, positive or negative attitudes depend on various factors, including success (Gutierrez et al. 2007, 56; Lasagabaster 2007, 79), or how socio-politically neutral a language is thought to be (Mettewie and Janssens 2007, 127; O'Laoire 2007, 179; Laugharne 2007, 219).

\section{Insight into Familiarity and Attitudes towards Eng- lish Words and Phrases in Croatian}

As noted above, English is the international lingua franca of the modern world and has, as a result, influenced Croatian on various levels. The increasing number of English linguistic elements in Croatian that can be read in the newspapers, heard on the television or even on the street, is indisputable evidence of how the language is changing. The influence of English on the Croatian language goes beyond Anglicisms because some English loanwords have been adapted to the language system and therefore can be tolerated. Discussions and debates are mainly focused on the growing number of unadapted English words and phrases which are used arbitrarily, despite the numerous Croatian alternatives that Croatian native speakers have at their disposal.

\subsection{Questionnaire Analysis}

A two-part questionnaire was used in the research. The first part was composed of 22 simple yes/ no statements which provide an outlook on English words and phrases in Croatian. The second part consisted of a list of English words and phrases commonly used in Croatian. Participants had 
to decide which of the words they were familiar with and to write down a Croatian equivalent, if they knew it. The results of the questionnaire were analysed according to the following variables: age, education level, and the number of years of learning English in school. It was carried out via the Internet using Google Docs Questionnaire.

The investigation involved 534 participants, including 293 who were younger than 25, 204 who were between $25-45$ years of age, and 37 who were older than 45 . These participants were further divided into groups according to the variables mentioned above. In terms of education level, a total of 4 participants had completed elementary school, 159 had finished high school, 39 had their bachelor's degree, 278 had their master's degree, and 54 had a PhD. Elementary school participants were not analysed as a distinct group due to the small number in this category. With regard to the number of years of learning English in educational settings, 16 participants had never learned English, 13 had learned English for less than 4 years, 261 had learned English between 4-12 years, and 244 had learned English for more than 12 years. Although there are differences in the number of participants in some educational groups, as well as in groups distinguished according to the number of years of learning English (which could not be controlled, given the way the questionnaire was conducted), we consider these variables relevant to our research. The descriptive analysis of the sample is presented in Figure 1. The results are discussed in the continuation of the paper.

\section{Variables}

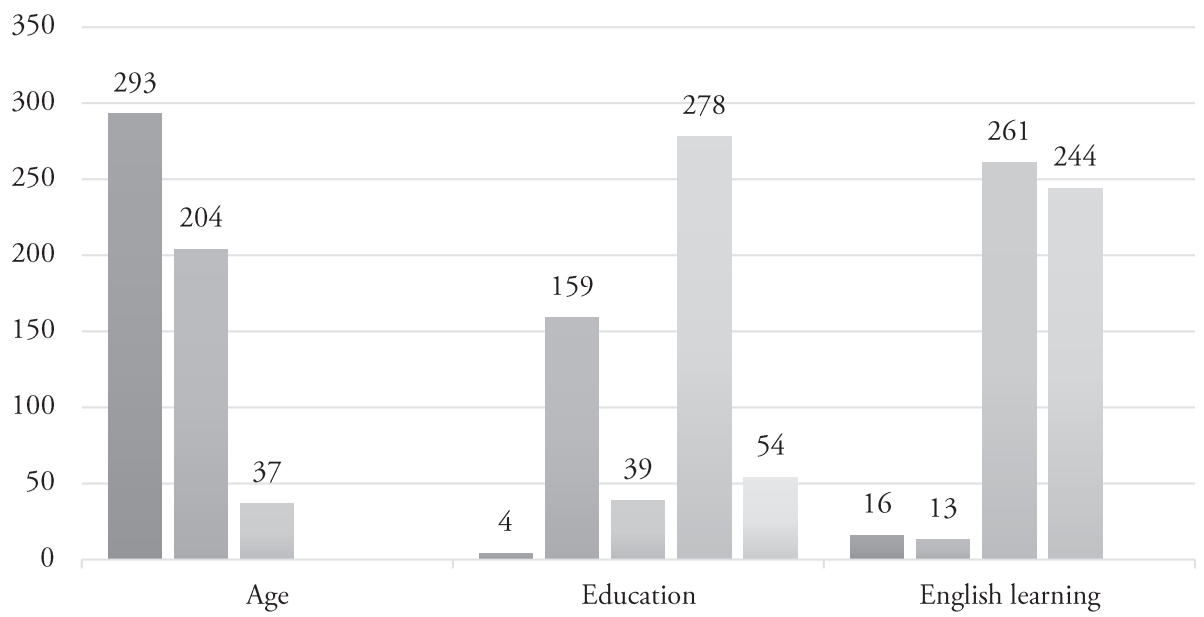

Figure 1. Frequencies: Age, education level, years of learning English

\subsection{Attitudes}

Informants' responses for the introductory statement, "I like the English language," reveal that attitudes towards English were mainly positive and that there were no differences according to the variables. Small percentages of those who did not like English became present as the number of participants in a group grew. Furthermore, the second statement, "I think that the use of the English language will grow even more in the future," showed that people were aware of the status of English in the world and in Croatia and agreed that English would become even 
more important in the future. However, the participants did not feel threatened by the English hegemony and the influence it has on languages. The third statement, "I think there is a possibility that English will replace Croatian completely in the future," shows that most of the participants strongly believed there was no need to fear that the Croatian language would become extinct. Perhaps such assumptions are based on periods from Croatia's past which entailed Italian and German hegemony, but which had passed without any severe consequences. Nevertheless, there were some participants who answered positively, and this percentage was higher compared to those few participants who did not like English.

The following statements were related to the amount of English words in Croatian and the areas in which such words appear. The participants could not decide whether there are too many English words in Croatian - for example, the results for statement number 4, "I think there are too many English words in Croatian," were predominately neutral. However, agreement with the statement grew with the age of the sample. According to the number of years of learning English, some differences were shown. Although the first two categories were smaller than the other ones, even this number of participants showed a connection between English knowledge and the presence of English. Namely, 62.5\% of those who had never learned English and 61.54\% of those who had learned it for less than 4 years thought that there are too many English words in Croatian, and this percentage became smaller as the level of English education increased.

Most of the participants thought that young people are the major users of English in everyday speech, as revealed by statement number 5, "I think that young people are mostly the ones who use English words in everyday speech." There were almost no differences according to age, education level, or the number of years of learning English with regard to this statement. English words and phrases in everyday speech were still considered the preference of younger generations. However, the area of use of English words in Croatian was not specifically defined. Participants were neutral towards statement number 6, "I think that English words are mostly used in the media." Moreover, in spite of the close number of those for and against the statement, all the groups showed a certain inclination towards it. The discrepancy was found only in the smaller groups - for example, $68.8 \%$ of the participants who had never learned English agreed with the statement, whereas among the participants who had learned English for less than 4 years, only 38.5\% of the participants agreed with it. The results are inconclusive with regard to the frequency of English words and attitudes towards Croatian. The participants were neutral towards statement number 7, "I think that the increased amount of English words in Croatian signifies carelessness towards the mother tongue." In spite of the close numbers of those for and against this statement, different groups were inclined towards one of the answers - for example, in the 25-40 age group, those who had learned English for 4-12 years, and those with a bachelor's degree agreed with the statement; however, the younger-than-25 age group, those that had learned English for more than 12 years, as well as those with high school education and master's degrees, disagreed with the statement.

Carelessness towards Croatian did not indicate that participants perceived the Croatian language to be undeveloped or poor, which is evident in the results of statement number 8 , "I think that the presence of English words in Croatian indicates the undeveloped state of Croatian and its indigence," where almost all the participants disagreed with the statement. This disagreement increased with age, education level and years of studying English. Furthermore, the groups who had never studied English or had studied it for less than 4 years had the lowest percentages, which implies that people who did not know English very well consider English words as a necessity because of the indigence of Croatian. 
Furthermore, participants did not see the presence of English words in Croatian as a threat to the identity of the Croatian language, as is claimed in statement number 9, "I think that the presence of English words in Croatian threatens the identity of the Croatian language." All the groups disagreed with the statement, but the strength of the disagreement varied, that is, the most common percentage was approximately 60 to 40 . According to the age variable, the middle generation felt the least threatened by the English language. It could be assumed that the disagreement grew with age, but after a certain age declined again. According to the education level variable, the results are inconsistent, whereas the disagreement grew with the number of years of studying English.

Even though the participants did not see the number of English words in Croatian as a threat to the identity of the Croatian language, they also did not see it as an enrichment or improvement of the language either, as claimed in statement number 10, "In my opinion, the increase of English words in Croatian represents enrichment of the language with some new English words. In that way language is improving." All the groups disagreed with this statement, but not strongly. The middle generation was mainly open to English words in Croatian and, although they might not improve the language, they did not feel threatened by them nor were they strongly opposed to borrowing. Moreover, the education level of the participants was also a factor; the higher the education level, the less they thought that English words could improve Croatian. The results for the number of years of studying English variable are too inconsistent to draw any conclusions; thus it may be stated that this variable does not significantly influence the statement.

Affective attitudes towards English words and phrases in Croatian were investigated in the statements 11 to 13. According to statement number 11, "The mixing of English words into Croatian bothers me," it appears that the older people did not like the mixing of English words into Croatian. On the other hand, education level had little influence on these attitudes, that is, the percentages of higher education were inconsistent. The participants who had spent more years studying English were less bothered and worried by the influence of English. Attitudes towards Croatian equivalents (statement number 12), "I think that Croatian equivalents are good enough and the use of English words in Croatian is unnecessary," showed almost no correlation for the age and education variables. The older generation valued Croatian equivalents and felt more protective than the younger generations, but the percentage of those younger than 25 who were protective of Croatian equivalents was higher than that of the middle generation. The results for the education level variable were inconsistent. However, the variable concerning length of studying English clearly confirms the introductory hypotheses - namely, as the level of English knowledge grew, the less participants felt protective and threatened by English. Nevertheless, the participants still valued Croatian equivalents, which is shown in the disagreement with statement number 13, "I think that we do not even need to look for Croatian equivalents for English words and phrases that we use often." Their disagreement was moderately strong with approximately around $55-60 \%$ of the participants in each category disagreeing with the statement. Only those older than 45 felt stronger about this statement, as well as those with a master's degree. The group that stood out was the group with high school education: $49.06 \%$ of participants disagreed with this statement. Although it is a small percentage, the participants in this group agreed more than they disagreed with this statement.

Furthermore, the inevitability of the influence of English is evident in the high percentages among participants who agreed with statement number 14, "I think that the use of English words in today's society is inevitable." Most of the percentages are around 75 to 85 percent. Length of studying English is not a relevant factor, but the younger generation, as well as the more 
educated groups felt more strongly about the inevitability of English. Moreover, the results for statement number 15, "It bothers me when I hear English words on a Croatian television program," support the hypothesis which stated that older generation as well as people with less knowledge of English dislike hearing English words in the Croatian context. This is probably due to the fact that they are not familiar with the language and do not understand everything. Participants younger than 25 and those from the 25-45 age group were not concerned by the use of English words on Croatian television programs: around $60 \%$ disagreed with the statement. However, $56.8 \%$ of the older generation agreed with the statement, indicating that they were disturbed by the use of English words on Croatian television. According to the level of education, participants are mostly not bothered by English words. With regard to length of studying English, most groups disagreed with the statement, except those who studied English for less than 4 years, who stated that they slightly agreed with the statement. Furthermore, the questionnaire addressed the question of the usage of English words in everyday speech in statement 16, "I often use English words in everyday speech." The results show that the percentage of participants who regularly used English words decreased with age. As expected, frequency of use increased with increased length of studying English, whereas according to the education level, the use of English was very high among all of the groups.

Moreover, most participants considered the use of English words and phrases as a way of promoting international understanding, which is evident in the results for statement number 17, "I think that the use of English words and phrases fosters international understanding," in which there was strong agreement among all the groups - for example, the percentage of those who agree was around 70 and 80 percent. However, the lowest percentage of agreement with the statement was found among participants older than 45, as well as those who had never studied English. Indeed, according to statement number 18, "It bothers me when people in my company unnecessarily use English words inside Croatian sentences," the percentage of people who were bothered by the unnecessary use of English words inside Croatian sentences increased with age. Education level had no influence on opinions about this statement. Moreover, it could be concluded that length of studying English slightly influenced the attitudes. In other words, the less that the participants had studied English, the more they were bothered by its unnecessary use.

Some participants considered English expressions better than Croatian ones, as can be seen from the results for statement number 19, "I think that some English expressions sound better than Croatian equivalents." According to the age variable, those younger than 25 and those in the 25-45 age group strongly agreed with this statement (more than 77\%), whereas those older than 45 just slightly agreed with the statement (54.1\%). Regarding education level, almost all the groups strongly agreed with the statement (around $80 \%$ ), with the exception of participants with a bachelor's degree (56.4\%). Moreover, regardless of the length of studying English, all the groups agreed with the statement; however, the groups with fewer years of studying English, did not agree to such an extent. On the whole, people claimed that they can express something more quickly and in a shorter form in English than Croatian. This presupposition is attested in statement number 20, "I think that we use English words and phrases more often because they can express something quicker and shorter." All the groups strongly agreed with this statement. The lowest percentages of agreement were found among participants who were older than 45 , those with a bachelor's degree, and those who had never learned English.

Finally, some of the participants admitted to consciously using English when they knew the Croatian equivalent because they liked English better. According to the results of statement 
number 21, "Even when I know a Croatian word, sometimes I use consciously English because I like it better," the use of English in everyday speech decreased with age. Education level did not influence the percentages significantly, whereas the conscious preference of English words increased within the group related to length of studying English. Moreover, according to statement number 22, "I often do not understand some English words used in the media," participants older than 45, as well as those who had never studied English, or studied it for less than 4 years, admitted that they sometimes did not understand some English words used in the media. All the other groups disagreed with the statement.

\subsection{Familiarity with English Words and Croatian Equivalents}

The second part of the questionnaire consisted of 20 English words and phrases often used in Croatian, some of them adapted to Croatian, some of them not. The words in the questionnaire were chosen on the basis of discussions by Opačić $(2006,2007,2012)$. In addition, they were noticed in newspapers. The participants had to decide whether the word was familiar to them and then were required to write down the Croatian equivalent. Remarkably, most of the words were familiar to all the groups, but when they needed to be explained, the percentages decreased even though many partial answers were accepted. The analysis of the examples will be presented in three groups. Firstly, the examples the participants were familiar with and for which they knew the Croatian equivalents, secondly, the examples the participants claimed to be familiar with, but showed lack of knowledge of Croatian equivalents, and thirdly, the examples the participants had some difficulties with.

To begin with, several English words and phrases in this part of the questionnaire were familiar to the participants and they knew the Croatian equivalents as well. A few examples: atacirati (from 'to attach' - priložiti), daunlodati (from 'to download' - skinuti s interneta), look (izgled), celebrity (poznata), slavna osoba ('famous person') or zvijezda ('star')), luzer (gubitnik) or breaking news (najnovije vijesti). Nevertheless, among the participants older than 45 and those who had never learned English, there were a few examples in which the wrong Croatian equivalents were chosen, like napadati ('to attack') for atačirati, for it was more difficult for them to admit that they did not know the word than it was for the younger or more educated generations. It is wellknown that increased language study facilitates familiarity with the language. Thus, the group who studied English for more than 12 years had the highest percentage of the correct Croatian equivalent for the Anglicism atačirati. Moreover, the percentage of participants familiar with the term daunlodati and those who knew the Croatian equivalent skinuti (s interneta) slightly dropped with age, whereas the group which gave most of the wrong answers were the participants who were older than 45. Education level had no impact on the results; the biggest discrepancy between familiarity with the term and knowing its Croatian equivalent was among participants with little or no knowledge of English. Moreover, the percentage of incorrect answers was the highest in those two groups as well.

Secondly, with regard to well-known English words and phrases, as participants claimed, the results reveal a lack of knowledge of Croatian equivalents, as well as misunderstanding of meaning. The results refer to the following examples: spiker (from speaker - govornik, voditelj), backstage (soba iza pozornice), blockbuster (najuspješniji film), developer (poduzetnik), involviran (from involved' - uključen), mobbing (zlostavljanje na radnom mjestu), all inclusive (uključujući sve), off the record (neslužbeno), and feedback (pouratna informacija). The older generation was more familiar with some of the examples than the younger generation was. The Anglicism spiker was familiar to all 
the groups. However, the percentages of knowledge of Croatian equivalents were visibly lower. The percentage of participants who knew the Croatian equivalent increased with age and years of studying English, whereas the education level variable showed no consistency. Furthermore, almost all of the participants claimed they were familiar with the example backstage, but the majority failed to give a correct Croatian equivalent and showed a lack of knowledge of meaning, defining it as pozornica ("stage") or stražnji ulaz ("back entrance"). In terms of the age variable, it was found that older participants were better at supplying Croatian equivalents compared to the younger ones. Some of them even used neologisms like zapozorje and zabinje. With regard to education level and length of studying English, it was found that the percentages increased both with the education level and the duration of language learning with the exception of correct answers (87.5\%) which were provided by the participants who had never learned English. The example blockbuster, referring to a very successful movie, was also familiar to the participants. However, knowledge of the Croatian equivalents and description of the term was not very high. Participants younger than 25 were less familiar with this example than the older generations were. The results for education level and language study showed a lack of consistency. Lack of knowledge of the meaning of the word was obvious from some of the answers given, which included defining the term blockbuster as velika reklama ("big poster") or najava filma ("film announcement"). In addition, the example mobbing was familiar to most of the participants, but there were some wrong answers when it came to providing the correct equivalent. The following equivalents were given for the term mobbing: koristenje interneta preko mobitela ("using the Internet via mobile phone"), zlostavljanje putem interneta ("bullying on the Internet"), rulja ("crowd"). Familiarity with the Croatian equivalent increased with age. Inconsistent numbers were found among the education level variable.

Moreover, the results of the expression all inclusive show that participants older than 45 had the highest percentage of correct Croatian equivalents, while the lowest percentage of correct answers was found among participants younger than 25 . Nevertheless, the situation was reversed when participants had to decide whether they were familiar with the term, namely, more participants younger than 25 were familiar with the term compared to those older than 45 . The percentages of correct Croatian equivalents increased with education level and with years of English language learning. However, many incorrect answers were given, for example, isključivo ("exclusive"), izloženo ("exposed"), samo odabrani ("only the chosen").

Finally, the example off the record was yet another expression which was highly familiar to participants. Regarding the age variable, the highest percentage of a correct Croatian equivalent was found among the participants from the $25-45$ age group. The other two groups had a significantly lower number of correct answers. In terms of education level, the highest percentage of correct Croatian equivalents was found among the participants with a bachelor's degree. Participants who had studied English the longest had the highest percentage of correct answers; however, the lowest percentage was found among the participants who had learned English for 4-12 years, not the participants who had never learned English, as was presumed. Nevertheless, some of the answers showed a complete lack of knowledge of the real meaning, for instance, $z a$ zapamtiti ("to be remembered"), da se zna ("for the record"), iza zastora ("behind the curtains"), izvan teme ("besides the point"), nepovjerljivo ("incredulously"), skinuti s ploče ("take off the board"), za tvoju informaciju ("for your information"). On the other hand, several examples were found to be more familiar among the younger generations. For instance, the example developer was more familiar among the younger generations, whereas the percentage of correct Croatian equivalents decreased with age. Furthermore, both the familiarity and the number of 
correct Croatian equivalents increased with the number of years learning English, whereas the education level variable showed no consistency. Moreover, in the example involviran, correct Croatian equivalents were the lowest among the participants older than 45. It was found that the percentages of correct answers increased according to the education level variable (high school - 76.7\%; PhD - 90.7\%), whereas participants who had never learned English had the lowest percentage of correct answers (43.8\%), while other groups among this variable had similar high results (around 83-89\%). The results reveal a spectrum of incorrect answers, including zaostao ("backward"), provociran ("provoked"), moderan ("modern”), izazvan ("prompted"). Finally, another example more familiar among the younger generation was feedback. The lowest percentage of correct answers was found among the participants older than 45, whereas the middle group had the highest percentage. The numbers were inconsistent with regard to education levels, whereas the percentage of correct Croatian equivalents increased with greater length of English language learning.

Several examples were not as familiar to the participants as others, and there were some difficulties with Croatian equivalents as well - for example, intimidirati (from "to intimidate" - zastrašiti, zastrašivati), play-off (doigravanje, odlučujuća utakmica or utakmica na ispadanje), approval rejting (from "approval rating" - stupanj podrške javnosti), prime time (udarno vrijeme), and rookie (početnik). The highest percentage of correct Croatian equivalents for intimidirati was among the middle age group and the lowest was among participants older than 45 . Inconsistent numbers were found in the education level variable, whereas an increase in the number of correct Croatian equivalents was found in participants who had studied English for a longer time. Incorrect answers were also found for this expression, for example, miješati se u nečiju intimu ("to interfere with somebody's privacy"), postati intiman ("to become intimate"), posredovati ("to intermediate"), zbližiti se ("to become more intimate"), prilagoditi ("to adjust"), biti točan ("to be precise"). Moreover, the participants gave numerous incorrect answers for the expression playoff, for instance, duel, iskljuciti ("to turn off"), odustati ("to give up"), prekini radnju ("to stop an action"), ugasiti ("to shut down"), isplata ("payoff"), zalecte ("offside”). Familiarity with the term, as well as the number of correct equivalents, increased with age. The numbers were irregular with regard to the education level variable, whereas the groups that had never learned English or learned it for less than 4 years claimed that they were 100\% familiar with the term. Participants who had never learned English had the most incorrect answers, and only $43.8 \%$ actually knew the correct Croatian equivalent. The group with the highest percentage of correct Croatian equivalents were the participants who had studied English for less than 4 years $(61.5 \%)$, whereas groups that had learned English longer had lower percentages.

Moreover, the number of correct Croatian equivalents for the expression approval rejting increased with age. However, the number of incorrect answers was highest among participants older than 45, whereas the participants younger than 25 mainly wrote that they did not know the answer. Regarding education level, the results were inconsistent; on the other hand, the percentages both of familiarity and of correct Croatian equivalents grew with the number of years spent learning English. Furthermore, the percentage of the participants familiar with the expression prime time increased with age as well. However, the percentage of correct Croatian equivalents was higher in the 25-45 age group compared to participants older than 45. Some of the incorrect answers reflect lack of knowledge, for example, prvo vrijeme ("first time"), primarno vrijeme ("primary time"), pravovremen ("timely"). The results for the education level and length of English language learning variables were irregular. Finally, the percentage of Croatian equivalents for the word rookie increased with age. The youngest and the oldest group had lower percentages of familiarity 
and knowledge of Croatian equivalents compared with the middle group. The results were inconsistent with regard to the education level and length of English language learning variables - the highest percentage of familiarity and correct Croatian equivalent was found among the participants with more than 12 years of language learning experience, and the lowest percentage was found among participants who had studied English for 4-12 years. Interestingly, some of the participants gave completely incorrect answers, for example, izvanredan ("exceptional"), profesionalac ("professional"), unovačen ("recruit"), propalica ("thug"), majstor ("craftsman"), lovac na talente ("headhunter").

\section{Conclusion}

Nowadays, English, as the major international lingua franca of the modern world, has a great influence on most languages and it has influenced the Croatian language on various levels as well. The aim of this paper was to explain the importance of language awareness and attitudes in practice, and the investigation attempted to complement such research in Croatia. The hypotheses were stated as follows: members of the younger generation are more familiar with popular English words and phrases and use them more often and, therefore, do not consider the amount of English words a problem; nor are they aware of the danger of such exposure to foreign linguistic influences. On the other hand, the older generation is not as familiar with popular culture and the Internet, so they will avoid using English and prefer Croatian equivalents. However, considering education, people with lower education levels will have the same attitudes as the older generation, while the more educated participants will be open to the influence of English.

The questionnaire began with the statement, "I like the English language," which was positively rated in all the categories. No differences were found among the age, education level and length of English language learning variables. Moreover, the participants were aware of the status of English in the world and Croatia and accepted that this influence would grow even more, but they still considered the increasing amount of English words in Croatian as the language of younger generations. The inevitability of English was strongly defended, they were not afraid of hegemony, they thought that there was no reason to fear the extinction of the Croatian language, and they supported the notion that English words and phrases could foster international understanding. On the other hand, the analysis focusing on the amount of English words in Croatian shows clear differences in age and language competence - that is, they confirm the hypothesis that older generations prefer Croatian equivalents because they are not that familiar with English. English words can be categorized as the language of youth, as young people admitted to using English words in everyday communication, but this was not the case for media language, as the participants were neutral towards English words in the media. Although the participants were aware of the presence of English words, they did not consider this to be carelessness towards their mother tongue. They disagreed with the statement that English words enrich the Croatian language, but they were not strongly opposed to it. Older participants were more concerned by the influence of English and the mixing of English words into Croatian and were less bothered with English language learning. Croatian equivalents were devalued among the younger generation and participants with higher knowledge of English. However, participants still thought that Croatian equivalents should be sought, but here the percentage was very low. Furthermore, the younger generation strongly believed that some English expressions sounded better than Croatian equivalents, and the older generation slightly agreed with them. English is considered to be compact and efficient and, according to some participants, a beautiful language. Nevertheless, most of the participants claimed that they could 
express something quicker and shorter with English words. Furthermore, the use of English in everyday speech was a characteristic found mainly among younger people and those who had studied English longer. All in all, it appears that adopting English vocabulary is not a necessity but a choice because Croatian does not lack the terminology. Bearing in mind Kowner and Rosehouse's list of motives and determinants for adopting loanwords (2008, 12-16), it should be noted that most English words in Croatian are adopted due to prestige and the influence of the mass media.

The second part of the questionnaire shows that some participants did not understand the meaning of English words and phrases commonly used in Croatian, which should be considered an appeal for change. However, it is interesting that the lack of Croatian equivalents mainly bothered the participants younger than 25; specifically, they claimed they were familiar with the words, but failed to give a Croatian equivalent. The terms they were most unfamiliar with included play-off, mobbing, approval rejting, prime time, all inclusive, off the record and rookie, whereas participants older than 45 did not know terms such as daunlodirati, feedback, intimidirati or involviran. With regard to the education level, the highest percentages of familiarity were found among the participants with a bachelor's degree, whereas the lowest percentages were found among the participants with a PhD. The lowest percentages of correct answers were found among the participants who had never learned English, while the highest percentage of correct answers was found among those with more than 12 years of English language learning, which confirms one of the hypotheses.

English is all around us, and although some people might think they know and understand it, the amount of incorrect answers shows otherwise. Answers like napadati ("to attack") for atačirati, postati intiman ("to become intimate") for intimidarati, or koristiti internet preko mobitela ("using the Internet via mobile phone") for mobbing are just some of the examples which clearly show the level of knowledge and awareness of English loanwords.

\section{References}

Aitchison, Jean. 2001. Language change: Progress or Decay? Cambridge: Cambridge University Press.

Andersen, Gisle. 2001. Pragmatic Markers and Sociolinguistic Variation. Amsterdam: John Benjamins Publishing Company.

—. 2014. "Pragmatic Borrowing." Journal of Pragmatics 67: 17-33. doi:10.1016/j.pragma.2014.03.005.

Anić, Vladimir. 1998. Jezik i sloboda. Zagreb: Matica hrvatska.

Babić, Stjepan. 1995. Hrvatski jučer i danas. Zagreb: Školske novine.

—. 2001. Hrvatska jezikoslovna prenja. Zagreb: Nakladni zavod Globus.

—. 2004. Hrvanja hrvatskoga. Zagreb: Školska knjiga.

Bainbridge, W. S. 2001. "Social Psychology." In Concise Encyclopedia of Sociolinguistics, edited by Rajend Mesthrie, 80-86. Amsterdam: Elsevier.

Baker, Colin. 1992. Attitudes and Language. Clevedon: Multilingual Matters.

Belaj, Branimir. 2009. "Leksik i identitet." In Jezični varijeteti i nacionalni identiteti, edited by Lada Badurina, Ivo Pranjković, and Josip Silić, 253-67. Zagreb: Disput.

Berns, Margie. 2007. “The Presence of English Sociocultural, Acquisitional and Media Dimensions." In In the Presence of English: Media and European Youth, edited by Margie Berns, Kees de Bot, and Uwe Hasebrink, 
1-15. New York: Springer.

Berns, Margie, Marie-Thérèse Claes, Kees de Bot, Riet Evers, Uwe Hasebrink, Ineke Huibregtse, Claude Truchot, and Per van der Wijst. 2007. "English in Europe." In In the Presence of English: Media and European Youth, edited by Margie Berns, Kees de Bot, and Uwe Hasebrink, 15-43. New York: Springer.

Brown, Carol. 2006. Social Psychology. London: SAGE Publications.

Cameron, Deborah. 1995. Verbal Hygiene. London: Routledge.

Clyne, Michael. 1972. Perspectives on Language Contact. Melbourne: Hawthorn Press.

—. 1977. "Intercultural Communication Breakdown and Communication Conflict: Towards a Linguistic Model and its Exemplification." In Deutsch im Kontakt mit anderen Sprachen/German in Contact with Other Languages, edited by Carol Molony, Helmut Zobl, and Wilfried Stölting, 129-46. Kronberg: Scriptor.

-. 2003. Dynamics of Language Contact. English and Immigrant Languages. Cambridge: Cambridge University Press.

Cook, Guy. 2003. Applied Linguistics. Oxford: Oxford University Press.

Cooper, Robert L. 1989. Language Planning and Social Change. Cambridge: Cambridge University Press.

Crystal, David. 2003. English as a Global Language. Cambridge: Cambridge University Press.

Drljača Margić, Branka. 2014. “Contemporary English Influence on Croatian: A University Students' Perspective." In Language Contact around the Globe. Proceedings of the LCTG3 Conference, edited by Amei Koll-Stobbe and Sebastian Knospe, 73-92. Frankfurt am Main: Peter Lang.

Filipović, Rudolf. 1986. Teorija jezika u kontaktu. Uvod u lingvistiku jezičnih dodira. Zagreb: Školska knjiga.

—. 1990. Anglicizmi u hrvatskom ili srpskom jeziku. Zagreb: Školska knjiga.

Garrett, Peter. 2010. Attitudes to Language. Cambridge and New York: Cambridge University Press.

Giles, Howard, and Andrew C. Billings. 2004. "Assessing Language Attitudes: Speaker Evaluation Studies." In The Handbook of Applied Linguistics, edited by Alan Davies and Catherine Elder, 187-210. Malden: Blackwell Publishing.

Gutierrez, Xaquin Loren, Antonio Fernandez Salgado, Isabel Suarez Fernandez, and Gakan Casares Berg. 2007. "Language Use and Language Attitudes in Galicia." In Multilingualism in European Bilingual Contexts. Language Use and Attitudes, edited by David Lasagabaster and Angel Huguet, 40-64. Clevedon: Multilingual Matters.

Holliday, Adrian, Martin Hyde, and John Kullman. 2004. Intercultural Communication. London: Routledge.

Jackson, Howard. 1988. Words and Their Meaning. New York: Longman.

Jonke, Ljudevit. 1953. "O upotrebi tuđih riječi." Jezik 1/2: 1-4.

Kowner, Rotem, and Judith Rosenhouse. 2008. "The Hegemony of English and Determinants of Borrowing from its Vocabulary." In Globally Speaking. Motives for Adopting English Vocabulary in Other Languages, edited by Judith Rosenhouse and Rotem Kowner, 4-19. Clevedon: Multilingual Matters.

Kordić, Snježana. 2010. Jezik i nacionalizam. Zagreb: Durieux.

Kotze, Ernst F. 2001. "Ethnicity and Language." In Concise Encyclopedia of Sociolinguistics, edited by Rajend Mesthrie, 324-29. Amsterdam: Elsevier.

Kovačić, Marko. 2007. “Jezično ravnodušje.” Jezik 54/2: 64-69.

Kramsch, Claire. 2004. “Language, Thought, and Culture." In The Handbook of Applied Linguistics, edited by Alan Davies and Catherine Elder, 235-61. Malden: Blackwell Publishing. 
Kryzan-Stanojević, Barbara. 2013. “Od forme do norme.” In Javni jezik kao poligon jezičnih eksperimenata, edited by Barbara Kryzan-Stanojević, 193-205. Zagreb: Srednja Europa.

Lasagabaster, David. 2007. “Language Use and Language Attitudes in the Basque Country.” In Multilingualism in European Bilingual Contexts. Language Use and Attitudes, edited by David Lasagabaster and Angel Huguet, 65-89. Clevedon: Multilingual Matters.

Lasagabaster, David, and Vitoria Gasteiz. 2004. "Attitude.” In Sociolinguistics. Soziolinguistik. Handbücher zur Sprach-und Kommunikationswissenschaft, edited by Herbert Ernst Wiegand, 399-405. Berlin and New York: Walter de Gruyter.

Laugharne, Janet. 2007. “Language Use and Language Attitudes in Wales.” In Multilingualism in European Bilingual Contexts. Language Use and Attitudes, edited by David Lasagabaster and Angel Huguet, 208-23. Clevedon: Multilingual Matters.

Leith, Dick. 1997. A Social History of English. London: Routledge.

Liebkind, Karmela. 1999. "Social Psychology." In Handbook of Language and Ethnic Identity, edited by Joshua A. Fishman, 140-51. Oxford: Oxford University Press.

Liu, Aijuan. 2010. “On Pragmatic Borrowing Transfer: Evidence from Chinese EFL Learner's Compliment Response Behaviour." Chinese Journal of Applied Linguistics 33 (4): 26-44.

McKenzie, Robert M. 2010. The Social Psychology of English as a Global Language. Attitudes, Awareness and Identity in the Japanese Context. Dordrecht: Springer.

Mettewie, Laurence, and Rudi Janssens. 2007. “Language Use and Language Attitudes in Brussels.” In Multilingualism in European Bilingual Contexts. Language Use and Attitudes, edited by David Lasagabaster and Angel Huguet, 117-43. Clevedon: Multilingual Matters.

Meyerhoff, Miriam. 2006. Introducing Sociolinguistics. London: Routledge.

Milroy, James, and Lesley Milroy. 1999. Authority in Language. Investigating Standard English. London: Routledge.

Oczkowa, Barbara. 2010. Hrvati i njihov jezik. Zagreb: Školska knjiga.

O’Laoire, Muiris. 2007. "Language Use and Language Attitudes in Ireland.” In Multilingualism in European Bilingual Contexts. Language Use and Attitudes, edited by David Lasagabaster and Angel Huguet, 164-83. Clevedon: Multilingual Matters.

Onysko, Alexander, and Esme Winter-Froemel. 2011. "Necessary Loans - Luxury Loans? Exploring the Pragmatic Dimension of Borrowing." Journal of Pragmatics 43 (6): 1550-67. doi:10.1016/j. pragma.2010.12.004.

Opačić, Nives. 2006. Hrvatski u zagradama. Globalizacijske jezične stranputice. Zagreb: Hrvatska sveučilišna naklada.

—. 2007. Hrvatski jezični putokazi. Od razdraganosti preko straha do ravnodušnosti. Zagreb: Hrvatska sveučilišna naklada.

—. 2009. "Globalizacija i mali jezici." In Lice i naličje jezične globalizacije, edited by Barbara KryzanStanojević, 43-53. Zagreb: Srednja Europa.

—. 2012. Hrvatski ni u zagradama. Globalizacijska jezična teturanja. Zagreb: Hrvatska sveučilišna naknada.

O'Reilly, Camille C. 2001. Language, Ethnicity and the State. Volume 2: Minority Languages in Eastern Europe post-1989. London: Palgrave.

Paddila, Amado M. 1999. "Psychology." In Handbook of Language and Ethnic Identity, edited by Joshua A. Fishman, 109-21. Oxford: Oxford University Press. 
Prince, Ellen F. 1988. "On pragmatic change: The borrowing of discourse functions." Journal of Pragmatics 12/5-6: 505-18. doi:10.1016/0378-2166(88)90045-8.

Romaine, Suzanne. 2004. “Language-Contact Studies.” In Sociolinguistics. Soziolinguistik. Handbücher zur Sprach-und Kommunikationswissenschaft, edited by Herbert Ernst Wiegand, 49-58. Berlin: Walter de Gruyter.

Simpson, J. M. Y. 2001. “Accent.” In Concise Encyclopedia of Sociolinguistics, edited by Rajend Mesthrie, 29397. Amsterdam: Elsevier.

Suarez Büdenbender, Eva-Maria. 2013. “Te conozco, bacalao': Investigating the Influence of Social Stereotypes on Linguistic Attitudes." Hispania 96/1: 110-34. doi:10.1353/hpn.2013.0031.

Thomason, Sarah G. 2001. Language Contact. Edinburgh: Edinburgh University Press.

Thurlow, C. 2001. “The Internet and Language.” In Concise Encyclopedia of Sociolinguistics, edited by Rajend Mesthrie, 287-89. Amsterdam: Elsevier.

Tišljar, Zlatko. 2002. Europska ideologija. Zagreb: Izvori.

Vikør, Lars. 2004. “Lingua Franca and International Language.” In Sociolinguistics. Soziolinguistik. Handbücher zur Sprach-und Kommunikationswissenschaft, edited by Herbert Ernst Wiegand, 328-35. Berlin: Walter de Gruyter.

Winter-Froemel, Esme, and Alexander Onysko. 2012. "Proposing a Pragmatic Distinction for Lexical Anglicisms." In The Anglicization of European Lexis, edited by Cristiano Furiassi, Virginia Pulcini, and Félix Rodríguez González, 43-64. Amsterdam: John Benjamins.

Žanić, Ivo. 2013. "Dokle su anglizmi - anglizmi? Nekoliko opaski o inkulturaciji tuđica.” In Javni jezik kao poligon jezičnih eksperimenata, edited by Barbara Kryzan-Stanojević, 205-20. Zagreb: Srednja Europa. 


\section{Appendix}

\section{Gender:}
a) $\mathrm{M}$
b) $\mathrm{F}$

Age:
a) less than 25
b) 25-45
c) older than 45

\section{Country:}
a) Croatia
b) other:

\section{Mother tongue:}

a) Croatian

b) other:

\section{Education level:}
a) elementary school
b) high school
c) Bachelor's degree
d) Master's degree
e) $\mathrm{PhD}$

I've learned English:
a) I have never learned English
b) Less than 4 years
c) 4-12 years
d) More than 12 years

Decide whether you agree with the statements above and choose YES or NO for each statement.

1. I like the English language.

2. I think that the use of the English language will grow even more in the future.

3. I think there is a possibility that English will replace Croatian completely in the future.

4. I think there are too many English words in Croatian.

5. I think that young people are mostly the ones who use English words in everyday speech.

6. I think that English words are mostly used in the media.

7. I think that the increased amount of English words in Croatian signifies carelessness towards the mother tongue.

8. I think that the presence of English words in Croatian indicates the undeveloped state of Croatian and its indigence.

9. I think that the presence of English words in Croatian threatens the identity of the Croatian language.

10. In my opinion, the increase of English words in Croatian represent enrichment of the language with some new English words. In that way language is improving.

11. The mixing of English words into Croatian bothers me.

12. I think that Croatian equivalents are good enough and the use of English words in Croatian is unnecessary.

13. I think that we do not even need to look for Croatian equivalents for English words and phrases that we use often.

14. I think that the use of English words in today's society is inevitable.

15. It bothers me when I hear English words on a Croatian television program

16. I often use English words in everyday speech.

17. I think that the use of English words and phrases fosters international understanding.

18. It bothers me when people in my company unnecessarily use English words inside Croatian sentences.

19. I think that some English expressions sound better than Croatian equivalents.

20. I think that we use English words and phrases more often because they can express something quicker and shorter. 
21. Even when I know a Croatian word, sometimes I use consciously English because I like it better.

22. I often do not understand some English words used in the media.

There is a list of Anglicisms and some English words and phrases often used in various media. Your task is to circle the words you are familiar with and write the Croatian equivalents of these words.

1. Atačirati

2. Daunlodati

3. Look

4. Celebrity

5. Spiker

6. Luzer

7. Play-off

8. Backstage

9. Approval rejting

10. Blockbuster

11. Developer

12. Prime time

13. Intimidirati

14. Involviran

15. Mobbing

16. Rookie

17. Breaking news

18. All inclusive

19. Off the record

20. Feedback 